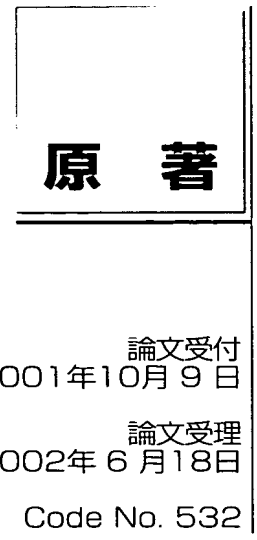

\section{胸部単純X線画像をドットプリンタで 出力するための画像処理法の開発}

\author{
下瀬川正幸・青山正人1）・Qiang $\mathrm{Li}^{2 ｝ \text { - 阿部裕之党 }$ \\ Feng $\mathrm{Li}^{2)} \cdot$ 白石順二 ${ }^{2)} \cdot$ 土井邦雄 ${ }^{2)}$ \\ 群馬県立医療短期大学診療放射線学科 \\ 1 ) 広島市立大学情報科学部知能情報システム工学科 \\ 2)シカゴ大学放射線科力ートロスマン放射線像研究所
}

\section{緒 言}

近年，“ドット密度の变調により写真濃度を表現す るプリンタ(以下，ドットプリンタ)”の性能と出力用 紙の品質が著しく向上している．ドットプリンタを用 いて医用画像を紙に出力したとき，診断情報が十分に 表現されていれば，手軽でかつ経済性の高い参照医用
画像として有用である。たとえば，読影レポート作成 時の参照添付画像としての利用や，さらに将来は，他 の医療機関への患者の転送, 紹介時に用いる複製画像 としての利用など，幅広い分野への応用が期待でき る.田原らは, computed tomography $(\mathrm{CT})$, magnetic resonance imaging (MRI) を対象としてドットプリンタ

\title{
Development of an Image Processing Scheme for Chest Radiographs Using a Dot Printer
}

MASAYUKI SHIMOSEGAWA, MASAHITO AOYAMA "), QIANG LI'2), HIROYUKI ABE²), FENG LI"2), JUNJI SHIRAISHI'), and KUNIO DOI ${ }^{2)}$

Department of Radiological Technology, Gunma Prefectural College of Health Sciences

1) Department of Intelligent Systems. Faculty of Information Sciences, Hiroshima City University

2) Kurt Rossmann Laboratories for Radiologic Image Research. Department of Radiology. The

University of Chicago

Received Oct. 9, 2001; Revision accepted June 18, 2002; Code No. 532

\section{Summary}

The performance of dot printers has recently been improved. Images output by dot printers can provide simple, economical medical reference images if important diagnostic information is not lost. We developed an image processing scheme for chest radiographs that employed a dot printer. We used two types of pixel value conversions, a nonlinear pixel value correction using a lookup table and a linear pixel value conversion using histogram analysis. The density distribution of chest radiographs was analyzed and classified into highdensity and low-density images. The two types of pixel value conversions were used depending on the density of chest radiographs. Converted pixel value had density characteristics that were adapted to the output image of the dot printer, and thus the density distributions of the lungs of radiographs became comparable. In addition, an adaptive unsharp masking technique with processing parameters optimized for each of the lungs and mediastinum was applied. An ROC study for the detection of lung nodules was carried out to evaluate the performance of dot printer images. The area under the ROC curve $\left(A_{z}\right)$ for dot printer images was 0.816 , while sensitivity and specificity were $77.6 \%$ and $75.2 \%$, respectively. The performance indicated the usefulness of our image processing scheme.

Key words: Dot printer, Image processing, Chest radiograph, Receiver operating characteristic (ROC) analysis, Lung nodule 
を用いて専用用紙に出力し，そのハードコピー画像の 利用が可能であることを報告している1ー3)。しかし， 胸部単純X線画像は, CTやMRIの画像に比べて一般に 高精細画像で，しかも肺野部から縦隔部にわたる広い 写真濃度領域を描出する必要がある。さらに，病変部 が淡い㓌影として現れることも多い。このような高画 質が要求される胸部単純X線画像を, ドットプリンタ を用いて出力するときに，どのような画像処理を用い るべきかについては，これまで報告されていない.

本研究では, 胸部単純X線画像を, ドットプリンタ を用いて専用用紙に出力する場合の画像処理法を開発 した。そして胸部腫溜㓌影の検出を例に，診断情報の 描出能について評価を行い，画像処理法の有用性を検 討した。

\section{1. 使用機器および画像試料}

ドットプリンタはEPSON社製 PM-820Cを用いた。 解像度は1,440dpi×720dpiである. 印字方式はインク ジェットで，写真濃度の表現はドット密度を組織的デ イザ法，䛊差拡散法などの手法で制御することにより 行い，256階調を奏現している。印刷用紙は三菱樹脂 社製吸水性フィルム (反射) PETベースを用いた。用紙 サイズはA4であり，胸部単純X線画像は $20 \mathrm{~cm} \times 20 \mathrm{~cm}$ のサイズで出力される。

プリンタドライバの設定項目のなかで，印刷の画質 に関わる項目には，“用紙種類”, “インク”, “モード 設定”がある．各設定は，“用紙種類”を“尃用光沢フィ ルム”，“インク”を“黑”，“モード設定”を“推奨設定” と，それぞれ選択した。ここで，“モード設定”を“推 奨設定”にすることは，プリンタドライバの設定項目 の，“用紙種類”，“インク”，“用紙サイズ”のみを指定 するだけで，自動的にドットプリンタ側で最適な設定 が行われることを意味する。

画像試料として，日本放射線技術学会が頒布してい る，“標準ディジタル画像データベース「胸部腫瘤㓌影 像および非腫瘤陰影像」”の画像を用いた4，5)。画像の マトリクスサイズは, $2,048 \times 2,048$ (ピクセルサイズは $0.175 \mathrm{~mm} \times 0.175 \mathrm{~mm}$ )である。画像処理にはUNIXワー クステーションを用いた。画像データは，白黒反転 後，量子化ビット数を 12 bit (4,096階調)から 10bit (1,024階調)に変換して使用した。画像処理後の画像 は, Windowsパーソナルコンピュータ上で，画像表示 ソフト“OSIRIS (University Hospital of Genova)”で表 示し，ドットプリンタで出力した6,7).

\section{2. 画像㚮理アルゴリズム}

Fig.1は，ここで開発された画像処理の概略を示 す.
最初に，原画像のピクセル值のヒストグラムを分析 し, 低い写真湮度の画像(以下，低濃度画像)と高い写: 真濃度の画像(以下，高濃度画像)の場合に分ける。次 に，2 種類のピクセル值操作を行った。“ルックアッ プテーブルを用いる非線形ピクセル值修正”は，ドッ トプリンタの入出力特性を考慮したルックアップテー ブルを用いて，肺野部から縦隔部にわたる胸部画像全 体の写真濃度の分布を，X線フィルム出力画像と同様 の写真濃度の分布になるようにピクセル值を修正する ものである。“ヒストグラム分析による線形ピクセル 值変換”は，画像のピクセル值のヒストグラムを分析 して，画像データごとに大きく異なっている肺野部の ピクセル值の分布が，画像間でほほ一定になるように ピクセル值を変換するものである．ここで，低濃度画 像と高濃度画像では, 2 種類のピクセル值操作の適用 順序を入れ替えている。この理由は, 肺野部のピクセ ル值の分布範囲を，より広くする(コントラストを高 める)ためであり，2-1 節で詳説する。

ピクセル值操作後の画像に対しては，周波数強調処 理を行った。手法としては，肺野部と縦隔部で処理パ ラメータを最適化した選択的ボケマスク処理を適用し た8ー10)

\section{2-1 2 種類のピクセル值操作}

2-1-1 ルックアップテーブルを用いる非線形ピクセ ル值修正

ドットプリンタの入出力特性，および，胸部画像デ ータをディジタル化するときに用いたものと同じ機種 のレーザディジタイザ(コニカ社製LD-4500)の入出力 特性を表した特性曲線をFig. 2に示す.これらの入出 力特性を用いて，ドットプリンタ出力画像の写真濃度 が, ディジタル化する前のX線フィルム出力画像の写 真濃度に一致するように，原画像のピクセル值を修正 した。たとえば，ディジタル化する前のX線フィルム の写真濃度 $D_{o}$ が, ディジタイザによりピクセル值 $P_{o} に$ 変換されるとする。次に，このピクセル值が，ドット プリンタで同一写真濃度として出力されるためには, ピクセル值 $P_{o}$ が $P_{c}$ に修正されることが必要になる。そ こで $D_{o}$ を変化させて,$P_{o}$ と $P_{c}$ との関係を調べれば, Fig. 3に示すような原画像のピクセル值と, 対応する 修正ピクセル值との関係が得られる。

ここで, 原画像の写真濃度はX線フィルムの透過濃 度 $\left(D_{T}\right)$, 出力画像の写真濃度は印刷用紙の反射濃度 $\left(D_{R}\right)$ である． $D_{T}$ と $D_{R}$ では，写真濃度の性質が異なる ため，测定された写真濃度が一致していても，観察者 が感じる写真濃度の印象が異なることが予想される。 $D_{R}$ と $D_{T}$ が， 1 対 1 で対応する場合のピクセル值修正曲 線を用いて，原画像のピクセル値を修正した画像を観 


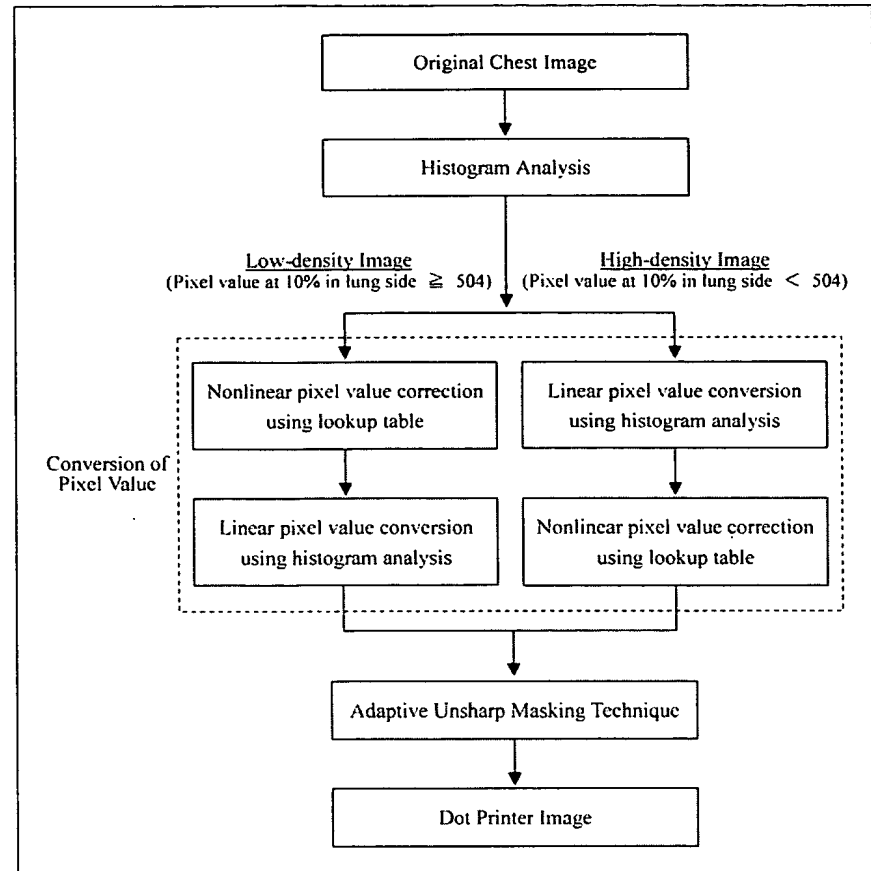

Fig. 1 Overall scheme of an image processing technique for a dot printer images.

察したところ，反射濃度が高いという印象を受けた． このため， $D_{R}=1.0 D_{T}$ のピクセル值修正曲線に加え， $D_{R}=0.9 D_{T}, D_{R}=0.8 D_{T}, D_{R}=0.7 D_{T}, D_{R}=0.6 D_{T}, D_{R}=$ $0.5 D_{T}$ と, 印刷用紙の反射濃度がX線フィルムの透過 濃度以下になるような, 合計 6 本のピクセル值修正曲 線を作成した。ここで, 修正後のピクセル值の最低值 は0になっていない。これは, Fig. 2のドットプリン 夕の特性曲線に示したように，ピクセル值が7以下で ある場合，写真濃度が飽和するためである。したがっ て，修正後のピクセル值の範囲は $7 \sim 1,023$ の值とし た.

次にこれらの非線形なピクセル值修正曲線のなか から, 原画像のピクセル值を修正するためのルックア ップテーブルを，以下に示す方法で求めた。 まず，胸 部画像データベースから肺野部の写真濃度 (以下, 肺 野濃度)が低いもの, 中間のもの, 高いものをそれぞ れ選択した．それらの画像の，ピクセル值のヒストグ ラムをFig. 4に示す. 次に，それぞれの画像に対し て, 前述の 6 本のピクセル值修正曲線を用いて 6 種 類のドットプリンタ出力画像を作成した. そして, 放 射線科医 2 名による主観的判断で, “肺野濃度が適し ていると感じられる画像”を決定した。 その結果, 肺 野濃度が低い画像では $D_{R}=0.9 D_{T}$ と $D_{R}=1.0 D_{T}$, 肺野濃 度が中間の画像では $D_{R}=0.8 D_{T}$ と $D_{R}=0.9 D_{T}$, 肺野濃度 が高い画像では $D_{R}=0.7 D_{T}$ と $D_{R}=0.8 D_{T}$ の条件のピクセ ル值修正曲線でピクセル值を修正した画像が，“肺野 濃度が適していると感じられる画像”として選択され

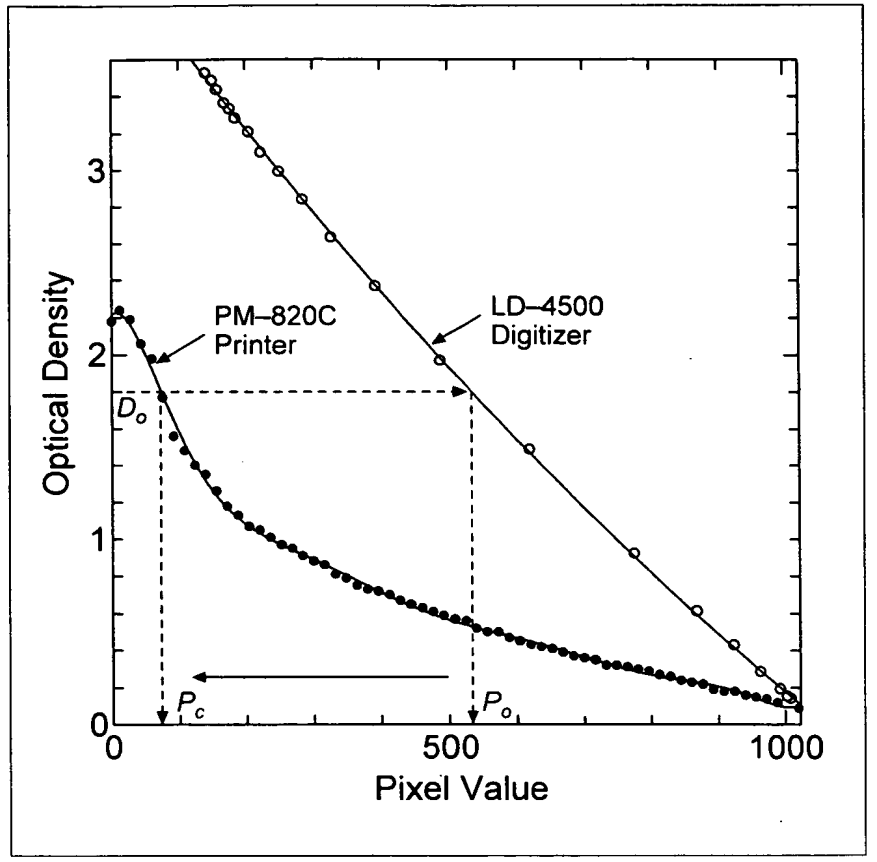

Fig. 2 Characteristic curves of the dot printer (EPSON PM$820 \mathrm{C}$ ) and laser digitizer (KONICA LD-4500).

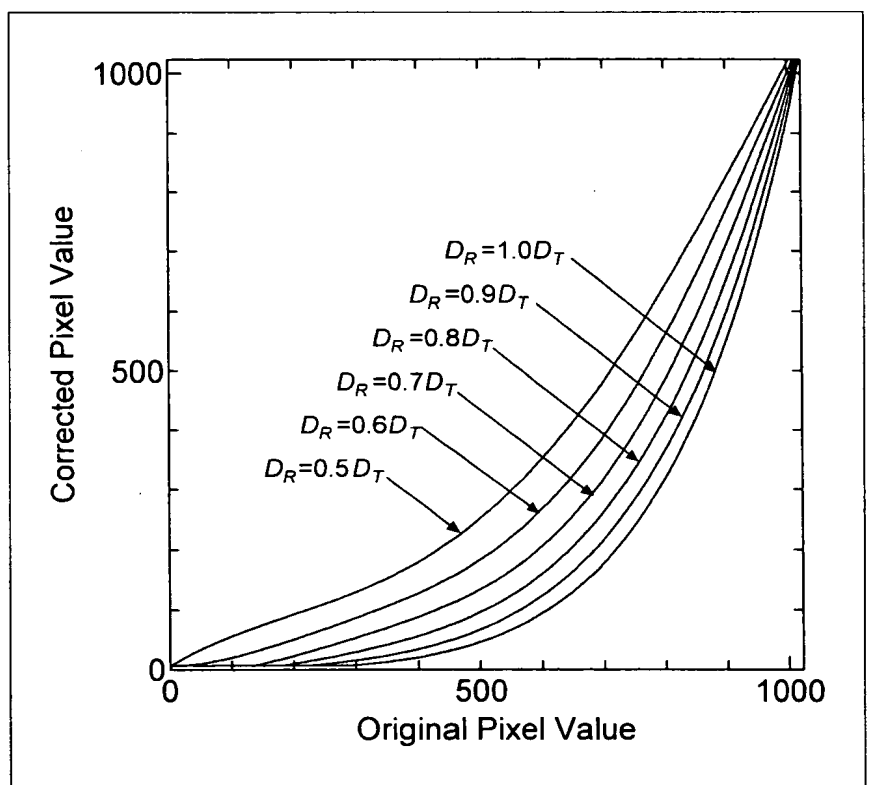

Fig. 3 Lookup tables of the nonlinear technique for pixel value correction. $D_{R}$ and $D_{T}$ indicate reflection density and transmission density, respectively.

た。そこで，肺野濃度が中間の画像を“基準画像”と定 義し，このときの $D_{R}=0.8 D_{T}$ と $D_{R}=0.9 D_{T}$ に対応するピ クセル值修正曲線を利用することとした。さらに， $D_{R}=0.8 D_{T}$ よりも $D_{R}=0.9 D_{T}$ の方が, 写真濃度のダイナ ミックレンジを広く利用できるという物理的な理由か ら， $D_{R}=0.9 D_{T}$ のピクセル值修正曲線を採用して全画 像データに適用した。つまり，ドットプリンタ出力画 


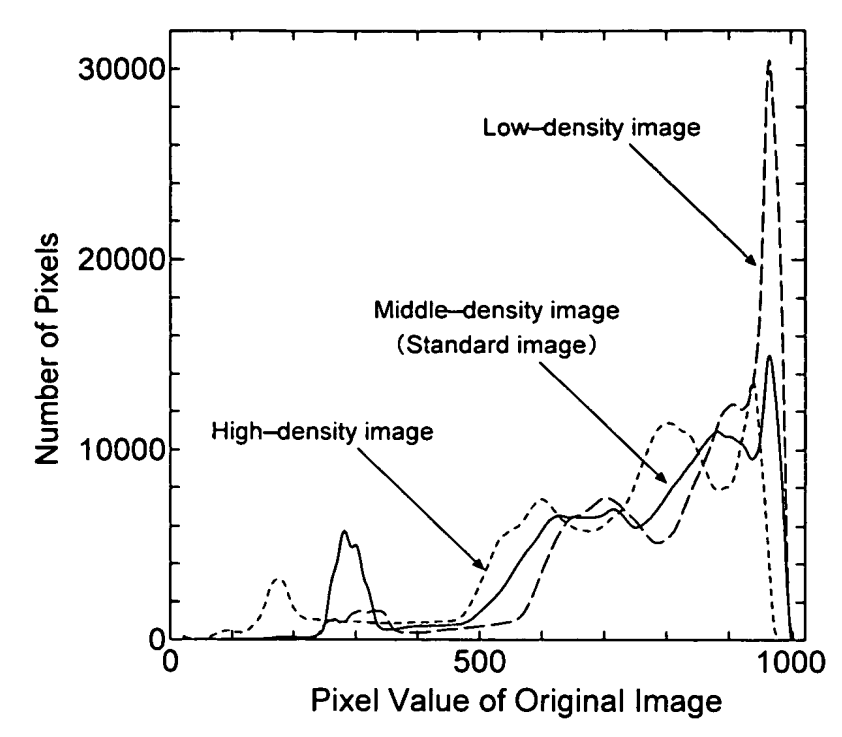

Fig. 4 Histograms for pixel values of chest radiographs at three different density levels.

像の反射濃度が，原画像の透過濃度の $90 \% に$ 対応する ようなピクセル值修正曲線を，本手法におけるルック アップテーブルとした.

ここで, “ルックアップテーブルを用いる非線形ピ クセル值修正”を適用するときには注意が必要であ る.なぜなら，Fig. 3で示したピクセル值修正曲線の 形状から分かるように，この修正処理には，低いピク セル值側 (高い写真濃度側) でダイナミックレンジ圧 縮, 高いピクセル值側(低い写真濃度側)でダイナミッ クレンジ拡張の効果が含まれるからである。つまり， 写真濃度が高い画像に対しでルックアップテーブル を用いる非線形ピクセル值修正”をそのまま行うと， 肺野部側 (高い写真濃度側)のピクセル值の分布範囲が 極端に狭くなる．そこで，肺野部のピクセル值の分布 範囲を広げるために, 原画像の写真濃度に応じてピク セル值操作の方法を变更することとした．

そのためにまず，ピクセル值操作を行う前に，原画 像のヒストグラムを分析して写真濃度のレベルを評価 した. ヒストグラム分析を行う画像内の領域は，直接 X線がヒストグラムの形状に与える影響を回避するた め, Fig. 5aの点線で示す胸部画像中央部 $1 / 4$ の面積の 領域を用いた"11)。この分析領域における“基準画像”の ヒストグラムをFig. 5bに示す。ここで，“基準画像”の ヒストグラムの，ピーク值の10\%のレベルに対する肺 野部側のピクセル值 (以下, 肺野部側 $10 \%$ ピクセル值) は504であった．そこで，未知の胸部画像に対して肺 野部側 $10 \%$ ピクセル值を求め, その值が504以上の場 合は, 低濃度画像と判断した12)。その場合には, 最初 に“ルックアップテープルを用いる非線形ピクセル值

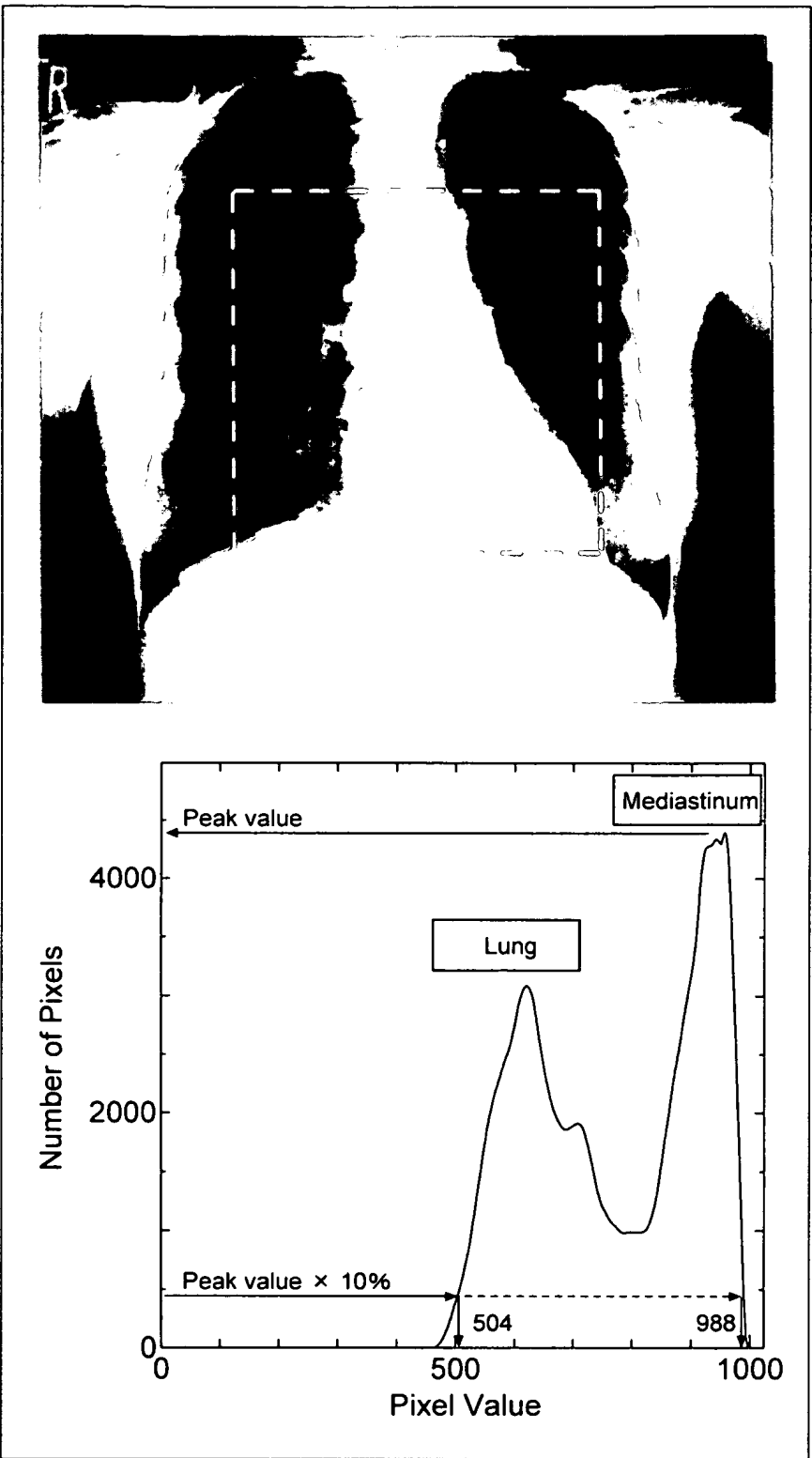

Fig. 5 Histogram analysis for judging density level in chest radiographs.

a: Region selected for histogram analysis.

b: Histogram for pixel values in the selected region of the "standard image."

\section{a b}

修正”を行い, 肺野部のピクセル值の分布範囲を広 げ，その後に，肺野濃度が“基準画像”の肺野濃度とほ ほ一致するように，2-1-2項で示す“ヒストグラム分析 による線形ピクセル值変換”を行った。一方, 肺野部 側10\%ピクセル值が504未満になる胸部画像の場合 は, 高濃度画像と判断した。この場合には, 最初に “ヒストグラム分析による線形ピクセル值変換”を行う ことによって, 肺野濃度が“基準画像”の肺野濃度とほ ほ一致するように，つまりピクセル值の分布が高くな る方向にピクセル值を変換し，その後に“ルックアッ プテーブルを用いる非線形ピクセル值修正”を行い, 肺野部のピクセル值の分布範囲を広げた。 


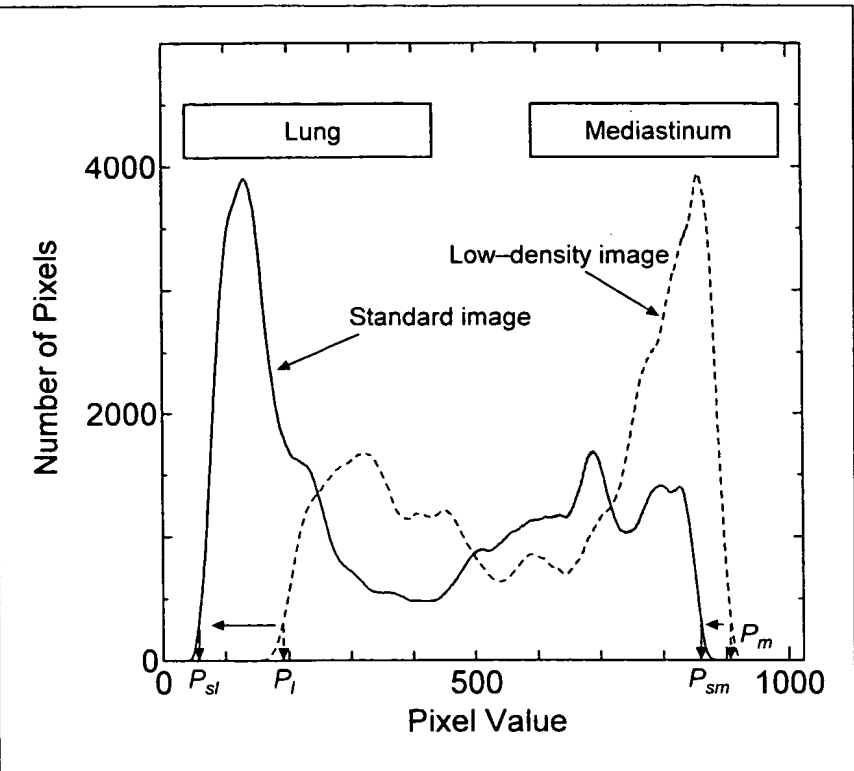

Fig. 6 Histograms for pixel values of the "standard image" and of a low-density image after "nonlinear pixel value correction using the lookup table."

2-1-2 ヒストグラム分析による線形ピクセル值変換

ドットプリンタの写真濃度のダイナミックレンジは 0.1 2.2であり (Fig. 2), X線フィルムのダイナミック レンジと比べて非常に狭い. 胸部画像全体の写真濃度 の分布が，狭いダイナミックレンジの範囲に入るよう にするためには, 各胸部画像の写真濃度の分布を, 大 体一定の值にする必要がある，具体的には，各胸部画 像のピクセル值のヒストグラムを分析して, “基準画 像”のピクセル值の分布とほぼ一致するようにピクセ ル值の変換を行うこととした。“基準画像”および肺野 濃度が低い画像の分析領域(胸部画像中央部 $1 / 4$ の面 積の領域)のヒストグラムをFig. 6に示す.ここで示し た“基準画像”のヒストグラムは，Fig. 5bで示したヒス トグラムを持つ“基準画像”に対して，既に“ルックア ップテーブルを用いる非線形ピクセル值修正”を適用 した後のものである.このため, Fig. 6 とFig. 5bでは “基準画像”のヒストグラムの形状が異なる.

ピクセル值の変換を行うために, 次の二つの尺度を 用いた。一つは, 前述の肺野部側10\%ピクセル值, 他 の一つは，ヒストグラムのピーク值の，10\%のレベル に対する縦隔部側のピクセル值 (以下, 縦隔部側 $10 \%$ ピクセル值)である. 肺野濃度が低い画像の肺野部側 $10 \%$ ピクセル值 $P_{l}$, および絴隔部側 $10 \%$ ピクセル值 $P_{m}$ を，Fig. 6に示すように，“基準画像”の肺野部側 10\% ピクセル值 $P_{s l}$, および縦隔部側 $10 \%$ ピクセル值 $P_{s m}$ に，それぞれ一致するようにピクセル值をシフトし た.このとき, $P_{l}$ と $P_{m}$ の間の各ピクセル值の変換は, “ $P_{l} \rightarrow P_{s l}$ ”, “ $P_{m} \rightarrow P_{s m}$ ”のシフト量に比例するように線

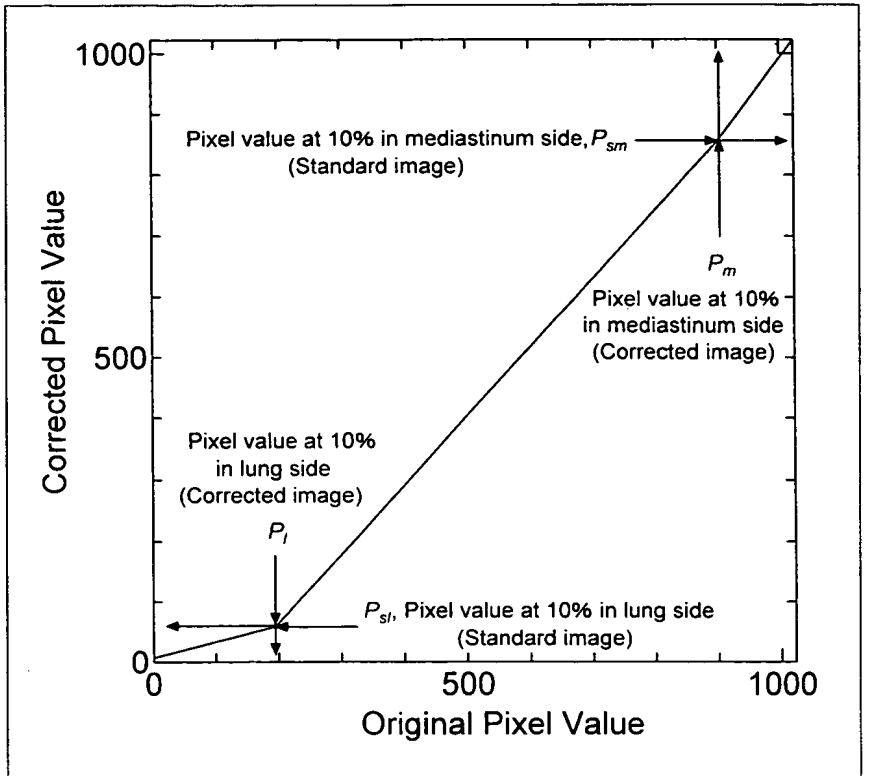

Fig. 7 Illustration of linear pixel value conversion.

形変換を適用した。 また, $P_{l}$ から $P_{m}$ までの範囲に属さ ないピクセル值 $\left(0 \sim P_{l}, P_{m} \sim 1,023\right)$ の変換は, 変換後 のピクセル值が飽和しないように7〜1,023の間に分 布するようにした．言い換えると，この処理は，変換 前後のピクセル值の対応関係を示したFig. 7におい て, 肺野部側 $10 \%$ ピクセル值 $\left(P_{l}, P_{s l}\right)$, および縦隔部 側10\%ピクセル值 $\left(P_{m}, P_{s m}\right)$ を区分点とする, 3 本の傾 きが異なる修正直線を用いて線形変換することに対応 する。この処理により, 各胸部画像の肺野部および縦 隔部のピクセル值分布を，ほほ一定にすることができ る.

\section{2-2 選択的ボケマスク処理による周波数強調}

ドットプリンタで出力した胸部単純X線画像を観察 したところ，高い空間周波数に相当する成分が劣化し て抢り, その結果, 従来のX線フィルム出力画像と比 べて, 腫㿖陰影の検出能が劣ることが予想された。 そ こで, ピクセル值操作を行った後の画像に対して, 以 下に示す方法で処理パラメータを決定した，選択的ボ ケマスク処理による周波数強調を行うこととした.

まず, 画像データベースから10例の胸部画像を選択 し，それぞれの画像に対して，7 種類のマスクサイズ $(17 \times 17,21 \times 21,25 \times 25,29 \times 29,33 \times 33,37 \times 37$, $41 \times 41)$, および 8 種類の重み係数 $(0.5,1.0,1.5$, $2.0,2.5,3.0,3.5,4.0)$ のボケマスク処理を行った画 像を作成した。これらの処理画像にボケマスク処理を 行っていない画像を加え, 2 名の放射線科医の主観的 な画像評価により，最も適当であると考えられる処理 パラメータを決定した。評価基準は, 肺野部に対して 
は，肺紋理が末梢まで良好に描出され，また，小粒状 に見えないこと，縦隔部に対しては，胸椎，心臓の裏 側の肺, 縦隔構造が良好に描出されていることとし た. 評価の結果, 肺野部の処理パラメータは, マスク サイズ $25 \times 25$, 重み係数 1.5 , 縦隔部の処理パラメータ は, マスクサイズ $37 \times 37$, 重み係数 3.0 と決定した.

奏際にボケマスク処理を行う場合の肺野部と縦隔部 の区別は，ピクセル值のヒストグラム分析によって決 定した.つまり，Fig. 8に示すように，胸部画像中央 部 $1 / 4$ の面積の領域のヒストグラムから, 肺野部と縦 隔部に対応する, 低ピクセル值領域と高ピクセル值領 域の，それぞれの領域ごとに局所ピークを検出し，そ の間にある最低頻度のピクセル值を求め, 肺野部と縦 隔部のピクセル值の境界と定めた。このピクセル值を しきい值としてボケマスク処理パラメータを変えた. 処理前，および処理後の画像の 1 例をFig. 9 に示す.

\section{ROC解析によるドットプリンタ出カ画像の評価}

\section{3-1 実験方法}

2 種類のピクセル值操作と選択的ボケマスク処理を 適用した本画像処理法の有用性を評価するために，本 手法によるドットプリンタ出力画像の䐧部腫瘤院影の 検出に関する receiver operating characteristic (ROC) 実験を行った。

観察者は, シカゴ大学と千葉大学の放射線科医で, 胸部放射線科医 1 名, 一般放射線科医 6 名の計 7 名 であった。経験年数は7 年から18年まで分布してい た. 観察試料としては, 画像データベースから30例の

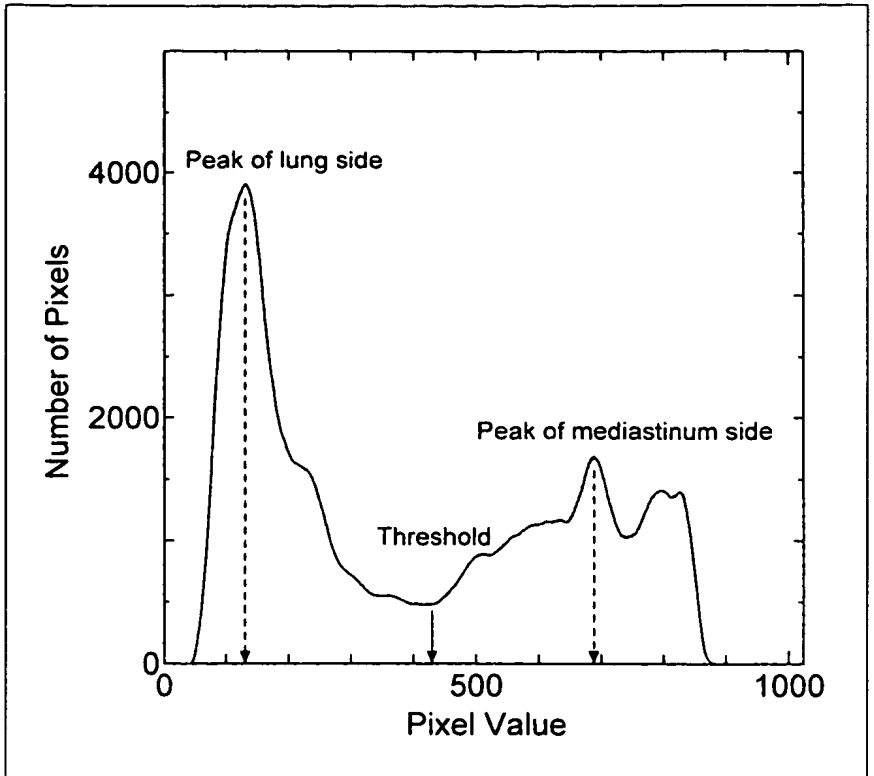

Fig. 8 Determination of threshold pixel value for an adaptive unsharp masking technique.

腫瘤除影を含む画像，および30例の腫瘤陰影なしの画 像をランダムに抽出し, 画像処理を行った後, ドット プリンタで出力したものを用いた，腫瘤院影を含むケ 一スには，読影難易度 2(検出が非常に困難)，読影難易 度 3 (検出が困難)，および読影難易度 4 (検出が比較的 容易)の，三つのレベルの難易度のものを用いた4，5). 読影難易度が両極端〔読影難易度 1 (検出が極端に困 難), 読影難易度 5 (検出が容易) ]のケースは除外し た。各レベルのケースの数は, 画像データベースに含

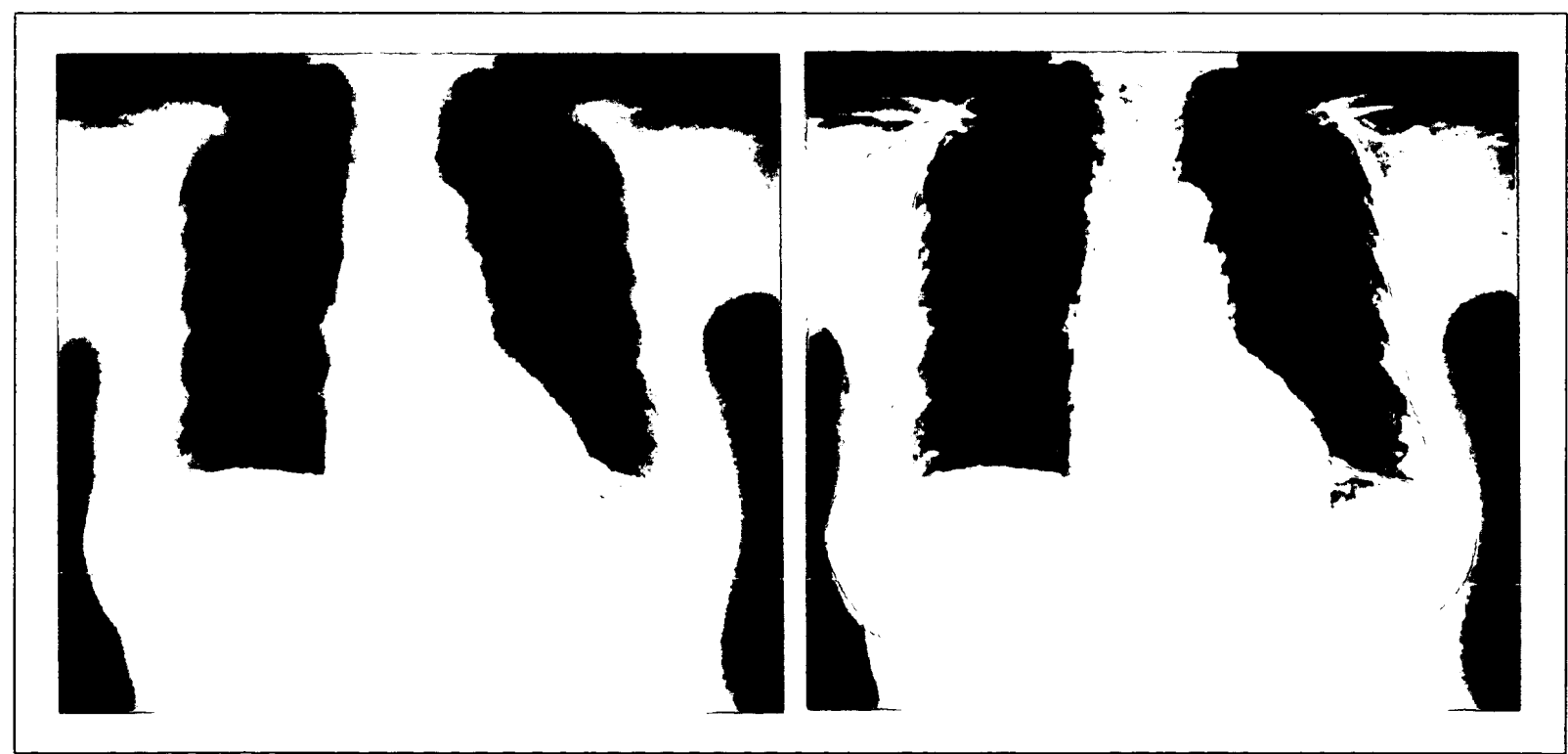

Fig. 9 Effect of adaptive unsharp masking technique on chest image (Lung: mask size $=25 \times 25$, weighting factor=1.5; Mediastinum: mask size $=37 \times 37$, weighting factor $=3.0$ ). a: Unprocessed image.

b: Processed image. 
まれている各ケースの数の分布と等しくなるように, 読影難易度 2 が 7 例, 読影難易度 3 が13例, および 読影難易度 4 が10例とした。

観察実験には，連続確信度法を用いた ${ }^{33)}$ 。これに は，長さ $5 \mathrm{~cm}$ の回答用のスケール（左端は腫瘤陰影な し，右端は腫瘤陰影あり)を用い，このスケールに， 観察者が各自の判断基準に応じて印をつけた，実験後 にスケールの左端から印の位置までの距離を読み取 り，これを確信度とした13)。なお，観察距離や観察時 間, そして読影室の照度などの観察環境は, 観察者に 任意に選択してもらった。

ROC解析用のソフトゥェアは，Metzらにより開発 された統合型ROC解析ソフト“ROCKIT”を用いた14).

\section{3-2 実験結果}

Tableに, 7 名の観察者全員のROC曲線から得られ たROC曲線下の面積 $\mathrm{A}_{\mathrm{z}}$ と経験年数を示す. $\mathrm{A}_{\mathrm{z}}$ の值は 0.657 から 0.908 の広い範囲に分布し，平均值は 0.816 であった．また，最大值50のスコアの中央值25をしき い值として，観察者のスコアを正答と誤答に分類して 求めた感度および特異度の平均值は，それぞれ，77.6 \%および75.2\%であった。

本実験の画像試料に用いた“標準ディジタル画像デ 一タベース「胸部腫瘤陰影像および非腫瘤陰影像」”で は，ディジタル画像データを，レーザプリンタを用い て実寸法のX線フィルムに出力した高画質の試料を用 いて，本実験と同様な手法で, 腫瘤陰影の検出に関す るROC実験が実施されている4,5). 本手法で出力され た画像を用いたROC実験の結果と比較するために，文 献4，5）で行われた実験の結果から，本実験で用いた ものと同じ60例の画像データに対する観察者のスコア を抽出し，それらのデータを用いて，X線フィルム出 力画像に対するROC曲線を求めた. Fig. 10に，ドット プリンタ出力画像およびX線フィルム出力画像に対す る, 観察者の平均ROC曲線を示す.X線フィルム出力 画像を観察試料として，20名の放射線科医から得られ た $\mathrm{A}_{z}$ の值は 0.785 から 1.000 の範囲に分布し, 平均值 は 0.901 であった.

\section{4. 考 察}

同じ症例を用いて行われたROC実験においては, 観 察者グループが異なっていても, 両者の差について, 統計的に有意差を検定することが可能であることが知 られている5， 12)。そこで，本実験で得られた $\mathrm{A}_{z}$ と，X

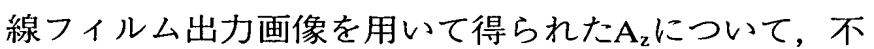
等分散両側 2 標本 $\mathrm{t}$ 検定を行った。その結果，ドット プリンタ出力画像から得られたROC曲線と, X線フィ ルム出力画像から得られたROC曲線の間には， $\mathrm{A}_{z}$ の
Table $A_{z}$ values (area under the ROC curve) for 7 radiologists.

\begin{tabular}{ccc}
\hline \hline Radiologist & $\begin{array}{c}\text { Experience } \\
\text { (years) }\end{array}$ & $\mathrm{A}_{\mathrm{z}}$ \\
\hline 1 & 18 & 0.865 \\
2 & 18 & 0.876 \\
3 & 13 & 0.908 \\
4 & 10 & 0.724 \\
5 & 9 & 0.887 \\
6 & 9 & 0.792 \\
7 & 7 & 0.657 \\
\multicolumn{4}{c}{ Mean of all observers : 0.816} \\
Standard deviation across observers : 0.095 \\
\hline
\end{tabular}

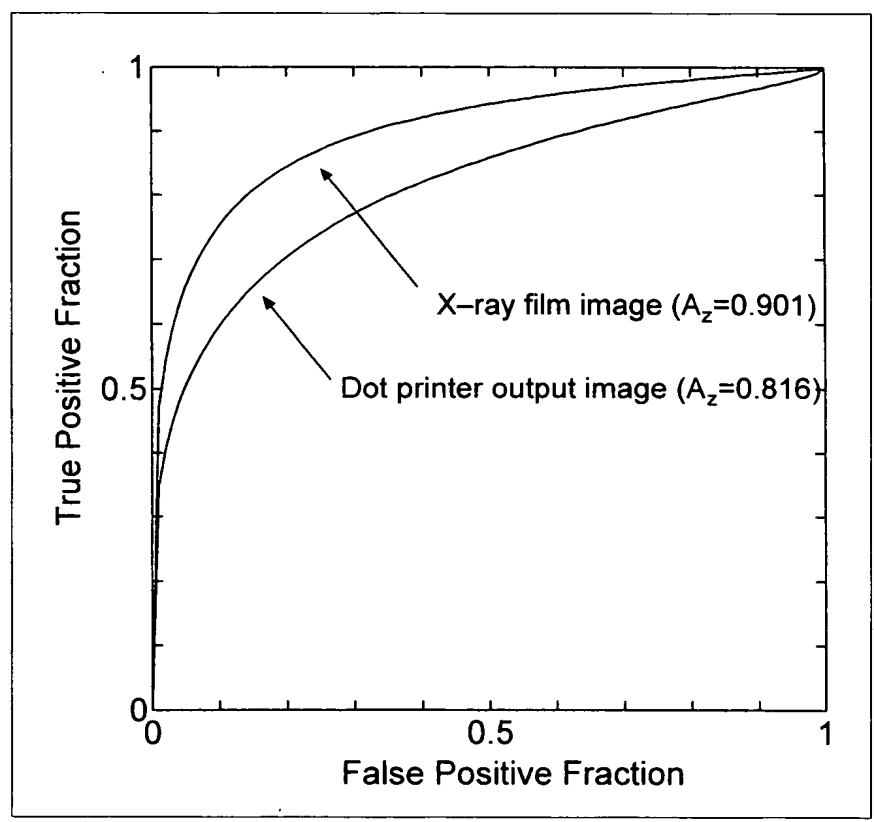

Fig. 10 Comparison of average ROC curves on dot printer images and $x$-ray film images.

平均值で約 0.1 の明らかな違いがあったが，危険率 5 \%では, 統計的な有意差は認められなかった $(\mathrm{p}=$ 0.057)。ここで, $\mathrm{p}$ 值は低いものの，両者の間に統計 的な有意差が認められなかった理由として，本実験に 参加した観察者の半数が, X線フィルム出力画像を用 いて20名の放射線科医から得られた平均の $\mathrm{A}_{\mathrm{z}}$ と，ほほ 同等の值を示したことに注目する必要があると思われ る．前述のように，同じ症例を用いたROC実験であれ ば，観察者グループが異なっていても統計的な有意差 を検定できるが，その場合は，観察者間の変動(各観 察者グループ内の分散)を考慮する必要がある。つま り，観察者の診断能の違いにより生じる差を考慮した 場合，今回の実験系においては，本画像処理法を適用 したドットプリンタ出力画像と, X線フィルム出力画 
像との間には，胸部腫瘤陰影の検出能において有意差 があるとは結論付けられないと考えられる.

ドットプリンタで出力された“参照画像”の画質が, 診断で要求されるX線フィルムのような高画質なもの に対して，どの程度の画質を満たせばよいかについて は，今後，議論すべき課題である。“参照画像”として の画質を考えたとき，すでにX線フィルム出力画像な どを用いて診断が下された病巣が，描出されているか どうかが重要であると考えられる．本手法により出力 された画像を用いた腫瘤陰影の検出に関する観察者実 験の結果から，本画像処理法を適用したドットプリン 夕出力画像を, 最初の診断に用いることが“適当であ る”と断定することは難しいが，“参照画像”として用 いるのであれば，比較的高い感度と特異度が得られる ものと期待される.

\section{5. 結 語}

胸部単純X線画像を，ドットプリンタを用いて専用 用紙に出力する場合の画像処理法を開発した。“ルッ クアップテーブルを用いる非線形ピクセル值修正” と, “ヒストグラム分析による線形ピクセル值変換”と いう 2 種類のピクセル值操作を提案した. 胸部画像の 濃度の高低に応じて, 2 種類のピクセル值操作の適用 順序を入れ替えることにより，ピクセル值は，ドット プリンタの入出力特性に適応した写真濃度と階調特性 を持ち, 肺野部および縦隔部の写真濃度が, 各胸部画 像でほほ一定になるような值に変換された。さらに， ピクセル值操作後の画像に対して, 肺野部と縦隔部で 処理パラメータを最適化した選択的ボケマスク処理に よる周波数強調を行った。

これらの画像処理を適用したドットプリンタ出力画 像の診断情報の描出能について, 腫瘤陰影の検出を例
にROC実験で評価した。 その結果， $\mathrm{A}_{z}$ が 0.816 , 感度 が $77.6 \%$, 特異度が $75.2 \%$ と, 比較的高い值が得ら れ, 本研究で対象とした腫瘤除影が, 正しく描出され ることを確認した。

ドットプリンタ出力画像においては，使用するプリ ンタ，インク，印刷用紙，それぞれの特性が画質に影 響を与える。このため, ドットプリンタで医用画像を 出力する場合の画像処理法は, 装置や材料が異なれ ば，その場合に応じて適用し直す必要がある。さら に, 扱う医用画像の種類に応じて, 求められる画質は 異なるため, 適用する画像処理法も異なると考えられ る. 今後, プリンタの高性能化が図られ, より高画質 なハードコピー画像を得ることが可能になると予測さ れる. 本研究は, 適切な画像処理を行ったドットプリ ンタ出力画像が, 将来, 手軽で経済性の高い, 参照医 用画像として用いられる可能性を示すものである.

\section{謝 辞}

本研究は，日本放射線技術学会平成12年度短期留学 生としてシカゴ大学カートロスマン放射線像研究所に 滞在している間におもに行われたものです。この短期 留学の機会を与えて下さった，日本放射線技術学会 川村義彦学会長はじめ会員諸兄の皆様に心からお礼申 し上げます。また，研究を行うにあたりご協力いただ いたシカゴ大学カートロスマン放射線像研究所の皆様 に感謝いたします。

ROC実験に参加していただいた，シカゴ大学，千葉 大学の観察者の先生方に深く感謝いたします。

三菱樹脂株式会社の田原一義氏，安良城盛太郎氏に は，実験に使用したドットプリンタと印刷用紙をご提 供いただきました。 


\section{参考文献}

1) 田原一義, 此川公紀, 久保田勝巳, 他：画像添付形式レポ ートシステムの試作一市販プリンターを利用した高画質画 像添付レポートシステム一，第19回医療情報学連合大会論 文集，932-933，(1999）。

2) 久保田勝巳, 石川光雄, 池田俊昭, 他 : パソコンとドット プリンタを利用した医用画像ハードコピーの検討，日本放 射線技術学会第54回総会学術大会一般研究発表後抄録, 291，(1998).

3）石川光雄，久保田勝巳，此川公紀，他：パソコンとドット プリンタを利用した医用画像ハードコピーの画像評価，日 本放射線技術学会第26回秋季学術大会一般研究発表徐抄 録，87，(1998）.

4）白石順二, 土井邦雄，桂川茂彦，他：標準ディジタル画像 データベースの構築，日放技学誌，54(3)，439-445， (1998).

5) Shiraishi J, Katsuragawa S, Ikezoe J, et al.: Development of a digital image database for chest radiographs with and without a lung nodule: ROC analysis on radiologists' performance in detection of pulmonary nodules. Am J Roentgenol, 174 (1), 71 $74,(2000)$.

6) Ligier Y, Ratib O, Funk M, et al.: Portable image-manipulation software: What is the extra development cost? J of Digit Imag, 5 (3), 176-184, (1992).

7) Ligier $Y$, Ratib O, Logean M, et al.: Object-oriented design of medical imaging software. Computerized Medical Imaging and Graphics, 18 (2), 125-135, (1994).

8) 阿部克己, 桂川茂彦, 佐々木康夫：胸部ディジタル画像に おける選択的画像強調処理の試み, Med Imag Tech, 9 (1), 52-62, (1991).

9) Abe K, Katsuragawa S, Sasaki Y, et al.: A fully automated adaptive unsharp masking technique in digital chest radiograph. Invest Radiol, 27 (1), 64-70, (1992).

10）阿部克己, 桂川茂彦, 佐々木康夫：胸部ディジタル写真に おける選択的画像強調処理法の画像評価(ROC解析), 日本 䀢放会誌，52(2)，164-171，（1992）。

11) Yoshimura H, Xu X-W, Doi K, et al.: Development of a high quality film duplication system using a laser digitizer: Comparison with computed radiography. Med Phys, 20 (1), 51$58,(1993)$.

12) 土井邦雄 : 放射線画像の研究における最近の話題, The Journal of TMIT, 5(2), 1-23, (1993).

13）白石順二：診断能の評価一ROC解析の実験方法一，日放技 学誌, 55(4), 362-368, (1999).

14) Metz CE, Herman BA and Shen J-H: Maximum-likelihood estimation of receiver operating characteristic (ROC) curves from continuously-distributed data. Statistics in Medicine, 17, 1033-1053, (1998).

Fig. 1 画像処理の概略.

Fig. 2 ドットプリンタおよびディジタイザの特性曲線.

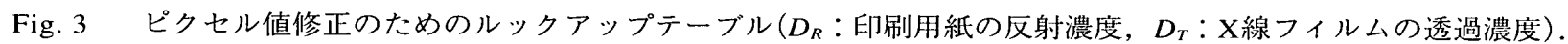

Fig. 4 肺野部の写真濃度が異なる 3 種類の画像に対するピクセル値のヒストグラム。

Fig. 5 胸部画像の写真濃度レベルを判断するためのヒストグラム分析.

(a) 分析領域.

(b) “基準画像”の分析領域におけるヒストグラム。

Fig. 6 “基準画像”および肺野部の写真濃度が低い画像の二つの画像に対して“ルックアップテーブルを用いる非線形ピクセル值修 正”を行った後の，分析領域におけるヒストグラム。

Fig. 7 線形ピクセル值変換。

Fig. 8 選択的ボケマスク処理のしきい值検出.

Fig. 9 選択的ボケマスク処理画像 (肺野部：マスクサイズ $25 \times 25$, 重み係数 1.5 , 縦隔部：マスクサイズ $37 \times 37$, 重み係数 3.0 ). (a) 処理前.

(b) 処理後.

Fig. 10 ドットプリンタ出力画像およびX線フィルム出力画像における平均ROC曲線.

Table 7名の観察者全員の経験年数とROC曲線下の面積 $\mathrm{A} \%$. 